\title{
The Barrabas Legacy: Race and Racism in Trump's America
}

\author{
Mamie E Locke* \\ Department of Political Science \& History, Hampton University, USA.
}

Submission: May 05, 2018; Published: October 03, 2018

${ }^{*}$ Corresponding author: Mamie E Locke, Department of Political Science \& History, Hampton University, USA. Email: Mamie.Locke@Hamptonu.Edu

\section{Opinion}

On November 8, 2016, Donald Trump received 304 electoral votes to Hilary Clinton's 227 votes. However, Clinton won both the popular vote and a higher percentage of victory than her opponent. Clinton received $65,794,399(48.2 \%)$ of the vote to Trump's $62,955,202(46.1 \%)$ of the vote, a difference of nearly 2.9 million votes [1]. While this was not the first presidential candidate to lose an election by winning the popular vote, it was a loss by the largest popular margin of any candidate in an election. Further, this election outcome has been discussed, debated, reviewed, and rehashed extensively as to what occurred. This was an election that many pundits and pollsters had Clinton winning by a fairly significant margin. After all, her opponent had held no elective office, had no political experience, and Clinton was up against an individual who had winnowed his way to the Republican nomination. How does one explain the inexplicable?

In a recent meeting of ministers an explanation of the 2016 election was given by an elected official in a spiritual context. He said that following the election his pastor gave a sermon that compared the election to Jerusalem citizens asking for the release of Barrabas, an individual claimed to be a notorious prisoner in the Gospel of Matthew, over Jesus. In each of the four gospels it is revealed that a Passover custom in Jerusalem was to commute a prisoner's death sentence by popular approval. When offered the choice of Barrabas or Jesus to be released, the crowd insisted that Pontius Pilate release Barrabas. That Barrabas moment, according to the pastor, was clearly an error in judgment, the crowd making the wrong choice. The results of the November 8, 2016 election demonstrated a Barrabas moment for many in America. Not for the first time had people chosen that which was not in their best interest. The consequences of that election have been especially impactful for race relations in the United States.

In Donald Trump's America, racism has been validated at the highest level of government because he has endorsed it as President of the United States. His bigotry was not new and was prevalent throughout his life and at the foundation of his campaign for the presidency. "Trump moved racism from the euphemistic and plausibly deniable to the overt and freely claimed" [2]. Throughout his campaign Trump made racist and bigoted remarks that demonstrated his disdain for people of color. He called a judge biased because he was a "Mexican." He refused to renounce white supremacist who campaigned for him. He called Mexican immigrants criminals and rapists. He lumped racial groups into monolithic minority collectives that he loves, like, "the Hispanics", "the blacks," "the Muslims" while denigrating the groups at the same time. He condoned the physical attack against an African American Black Lives Matter protester by his supporters, claiming that the man "should have been roughed up" [3].

Donald Trump's racist America did not begin with his inauguration as the $45^{\text {th }}$ President of the United States [4]. His public life has been obsessed with making racist remarks dating back to his time as a real estate developer in New York City. He was sued twice by the government for refusal by his real estate company to rent to African Americans in the 1970s. He treated his African American employees in his casinos with disdain, claiming that "laziness is a trait in blacks." In 1989 he took out ads in New York newspapers calling for reinstatement of the death penalty and bringing back the police for five black and Latino teenagers accused of raping a wite woman in Central Park. He continued to claim they were guilty as late as October 2016 although DNA evidence had exonerated them [4]. He became the poster boy for birtherism, the racist conspiracy theory movement claiming that President Barack Obama was born in Kenya, not the United States. He also took out ads denigrating Native Americans, alleging that Mohawks had a well-documented record of criminal activity (Ibid).

According to the Southern Poverty Law Center [5], Donald Trump has opened the doors of the White House "to extremism, not only consulting with hate groups on policies that erode our country's civil rights protections but enabling the infiltration of extremist ideas into the administration's rhetoric and agenda" (SPLC, 2017). The radical right was previously on the fringes but found itself with a friend in the White House. Trump hired extremist advisors at the outset, such as Steve Bannon from Breitbart News as his chief strategist and Stephen Miller, an antiMuslim extremist, as his senior advisor for policy (SPLC, 2017). The SPLC indicates that race incidents increased once Donald Trump became president. An atmosphere of intimidation and fear has been created as well as an environment that says overt racism 
is acceptable. Incidents have ranged from Nazi and racist graffiti being spray painted with references to Trump, middle school students shouting, "build the wall," pro-Trump racist messages left at a church, to anti-semitic graffiti (Politti, 2016). Data from the Pew Research Center [6], indicate that most Americans believe that Trump's election has led to worse race relations in the United States. Overall, $60 \%$ of Americans believe Trump's election has caused race relations to become worse. Also, more of the public thinks that not enough attention is being paid to race and racial issues, with young adults more likely to believe this than older adults [6].

In Donald Trump's America, there is every effort to change the narrative from issues of race and racism. He would declare that he is not racist, but evidence to the contrary demonstrates otherwise. Incidents such as those with Starbucks, the Waffle House, Roseanne Barr's racist tweet, or the NFL players kneeling get deflected, either to something it is not, or to Trump himself. For example, the NFL players kneeling was about law enforcement mistreatment of African Americans and police brutality. That narrative was changed by Trump to respect for the flag and the national anthem and ultimately led to an NFL policy change about kneeling during the national anthem. The entire issue of police brutality against African Americans was dismissed with Trump ranting about players leaving the country and calling players "SOBs". Mara Gay, editorial board member for the New York Times, states that Trump uses racism as a political tool simply to distract from the real issues [7].

The negative impact of the tax bill, the separation of families at the border, budget cuts in education, health and human service programs that are detrimental to millions of families are not part of American policy discussions. When the issue of Russian interference with the 2016 election and Trump collusion emerge, Trump changes the narrative, usually to a negative, blatant, generally false Twitter rant that plays to his alt-right base. Rather than making America great again, Donald Trump infuses the environment with a toxicity that serves as a reminder of the Barrabas legacy of making bad choices and having to live with those choices. While one may accept that racism in Trump's America is a part of that legacy and American political life for the moment, future elections will give other choices and provide an opportunity for redemption.

\section{References}

1. National Archives and Records Administration U.S. Electoral College (2016) Presidential Election.

2. Coates, Ta-Nehisi (2017) The First White President: The Foundation of Donald Trump's Presidency is the Negation of Barack Obama's Legacy. The Atlantic.

3. O'Connor Lydia, Marans, Danie Here are 13 Examples of Donald Trump Being Racist.

4. Donald Trump's Racism: The Definitive List. (2018) New York Times, USA.

5. Southern Poverty Law Center (2017) 100 Days in Trump's America.

6. Doherty Carroll, Kiley Jocelyn, Johnson Bridget (2017) Most Americans Say Trump's Election Has Led to Worse Race Relations in the US. Pew Research Center.

7. Gay Mara (2018) Panel Discuss on MSNBC's Politics Nation with Reverend Al Sharpton.

\begin{tabular}{|l|}
\hline \multicolumn{1}{|c|}{ Your next submission with Juniper Publishers } \\
will reach you the below assets \\
- Quality Editorial service \\
- Swift Peer Review \\
- Reprints availability \\
- E-prints Service \\
- Manuscript Podcast for convenient understanding \\
- Global attainment for your research \\
- Manuscript accessibility in different formats \\
( Pdf, E-pub, Full Text, Audio) \\
- Unceasing customer service \\
Track the below URL for one-step submission \\
https://juniperpublishers.com/online-submission.php \\
\hline
\end{tabular}

